\title{
Correction: Rapid chemokinetic movement and the invasive potential of lung cancer cells; a functional molecular study
} Kam-Meng Tchou-Wong ${ }^{\dagger}$, Sandra YY Fok ${ }^{\dagger 2}$, Jeffrey S Rubin ${ }^{3}$, Fiona Pixley ${ }^{4}$, John Condeelis ${ }^{4}$, Filip Braet ${ }^{2}$, William Rom ${ }^{1}$ and Lilian L Soon*2

Address: ${ }^{1}$ Departments of Medicine and Environmental Medicine, Division of Pulmonary and Critical Care Medicine, NYU School of Medicine, New York, NY 10016, USA, 2 Electron Microscope Unit, Australian Key Centre for Microscopy and Microanalysis, University of Sydney, Sydney, NSW, 2006, Australia, ${ }^{3}$ Laboratory of Cellular and Molecular Biology, NCI, National Institutes of Health, Bethesda, MD 20892, USA and ${ }^{4}$ Department of Anatomy and Structural Biology, Albert Einstein College of Medicine of Yeshiva University, Bronx, NY 10461, USA

Email: Kam-Meng Tchou-Wong - tchouk02@med.nyu.edu; Sandra YY Fok - sfok5959@mail.usyd.edu.au; Jeffrey S Rubin - rubinj@mail.nih.gov; Fiona Pixley - pixley@aecom.yu.edu; John Condeelis - condeeli@aecom.yu.edu; Filip Braet - filip.braet@emu.usyd.edu.au; William Rom - William.Rom@med.nyu.edu; Lilian L Soon* - Lilian.Soon@emu.usyd.edu.au

* Corresponding author †Equal contributors

Published: 22 February 2007

BMC Cancer 2007, 7:32 doi:10.1/86/147|-2407-7-32
Received: 12 December 2006

Accepted: 22 February 2007

This article is available from: http://www.biomedcentral.com/I47/-2407/7/32

(C) 2007 Tchou-Wong et al; licensee BioMed Central Ltd.

This is an Open Access article distributed under the terms of the Creative Commons Attribution License (http://creativecommons.org/licenses/by/2.0), which permits unrestricted use, distribution, and reproduction in any medium, provided the original work is properly cited.

\section{Abstract}

This is a correction of an earlier published article.

Although Dr. Tchou-Wong and Dr. Rom were originally meant to be first and seventh authors, respectively, they were left off the authorship list when this manuscript was submitted to BMC Cancer [1]. We sincerely apologise to Dr. Tchou-Wong and Dr. Rom, and have reinstated them to their appropriate places within the author list.

Funding sources for this research include MO1-RR00096, RO1-ES0916 and NHMRC402510.

In addition, improper software conversion resulted in missing histogram bars in figure 7 of the article. This is corrected in figure 1 .

\section{References}

I. Fok SY, Rubin JS, Pixley F, Condeelis J, Braet F, Soon LL: Rapid chemokinetic movement and the invasive potential of lung cancer cells; a functional molecular study. BMC Cancer 2006, 6(I): 151 .

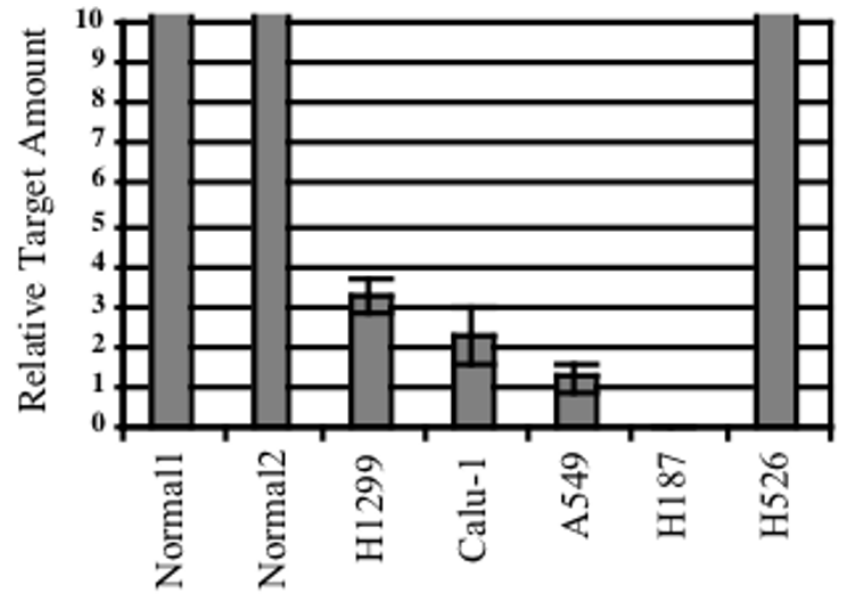

Figure I

The expression of ROM is downregulated in lung cancer cell lines. Real-time PCR detected high levels of ROM in normal lung tissue and in the small cell lung cancer H526. The presence of ROM was, however, strongly reduced in several other lung cancer cell lines; HI299, Calu- I, A549 and HI87. 